\title{
O HERETYKU MAHOMECIE - OPOWIEŚĆ O NARODZINACH ISLAMU W LATOPISIE HELLEŃSKIM I RZYMSKIM DRUGIEJ REDAKCJI**
}

\author{
ON THE HERETIC MUHAMMAD - AN ACCOUNT \\ OF THE ORIGIN OF ISLAM IN THE SECOND REDACTION \\ OF THE HELLENIC AND ROMAN CHRONICLE
}

\begin{abstract}
A piece of writing On the Heretic Muhammad concerning the life of Muhammad, the origin of Islam and the first Arab conquests in the $7^{\text {th }}$ century is included in the second redaction of the Hellenic and Roman Chronicle, a medieval Russian historiographical source containing an outline of universal history. The aforementioned text was edited and translated into Polish following the manuscript of РГБ, собр. Пискарева (228), № 162, from 1485.
\end{abstract}

Keywords: Muhammad, Islam, Old Russian literature, Hellenic and Roman Chronicle

Dzieje i kultura Arabów, okoliczności powstania islamu oraz życiorys Mahometa były zagadnieniami, które - jak odnotowano już w literaturze przedmiotu nie cieszyły się znacznym zainteresowaniem twórców staroruskich. Jest faktem, iż w średniowiecznej literaturze polemicznej z obszaru Slavia Orthodoxa (a zwłaszcza z jego wschodniej części) wyobrażenia religijne muzułmanów zajmują o wiele mniej miejsca niż judaizm czy chrześcijaństwo łacińskie (Лихачев 1979, s. 10-11; Батунский 2003, s. 73, 191; Bushkovitch 2010, s. 118-121, 142-143). Nie można jednak twierdzić, że wątki te są całkowicie nieobecne w piśmiennictwie ruskim z XI-XVI wieku. Wśród zabytków, na których kartach zamieszczono mniej lub bardziej rozbudowane sekwencje, poświęcone osobie założyciela islamu i głoszonym przez niego poglądom, na szczególną uwagę zasługują kompilacyjne utwory historiograficzne, prezentujące wykład dziejów powszechnych. Ich anonimowi autorzy,

* ORCID: 0000-0001-5951-3781; Katedra Filologii Słowiańskiej, Wydział Filologiczny, Uniwersytet Łódzki, ul. Pomorska 171/173,90-236 Łódź; zofia.brzozowska@uni.lodz.pl.

** Niniejszy artykuł powstał w ramach projektu sfinansowanego ze środków Narodowego Centrum Nauki, przyznanych na podstawie decyzji nr DEC-2016/23/B/HS3/01891 (Mahomet i narodziny islamu - stereotypy, wiedza i wyobrażenia w kręgu kultury bizantyńsko-ruskiej). 
bazujący przede wszystkim na tekstach bizantyńskich, znanych w staro-cerkiewno -słowiańskim przekładzie (m.in. kronikach Jerzego Mnicha zwanego Hamartolosem i Konstantyna Manassesa), postrzegali wystąpienie Mahometa jako wydarzenie o pierwszorzędnym znaczeniu z punktu widzenia historii basenu Morza Śródziemnego, a nawet szerzej - całej chrześcijańskiej ekumeny. I tak, dość obszerne narracje na temat muzułmańskiego proroka, zazwyczaj opatrzone wiele mówiącym tytułem $O$ heretyku Mahomecie (W Бохнитє єяєтиц'Е) lub Opowieść o haniebnej

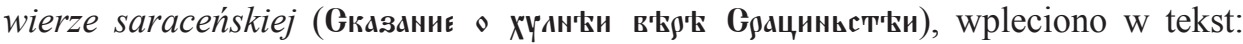
Chronografu Troickiego (XIII-XIV w.) (Творогов 1989, s. 336-338), Latopisu helleńskiego i rzymskiego drugiej redakcji (XV w.), Chronografu Rogożskiego (XV w.) (Анисимова 2010, s. 67-69), obu redakcji Chronografu Ruskiego (Русский хронограф 1911, s. 308-309; Русский хронограф 1914, s. 122-124), Latopisu Zmartwychwstania (XVI w.) (Летопись по Воскресенскому списку 1856, s. 249), Latopisu Nikonowskiego (XVI w.) (Летописный сборник 2000, s. 59-63) oraz Iluminowanego zwodu latopisarskiego (XVI w.) (Лицевой летописный свод XVI в. 2014, s. 389-398). Niekiedy opowieści te, niejako wyabstrahowane ze swojego pierwotnego kontekstu narracyjnego, odnajdujemy również w obrębie rękopisów typu miscellanea, np. manuskryptu РГБ, ф. 113.145(506) z XV stulecia (fol. 60-66') (Клосс 1980, s. 171; Bushkovitch 2010, s. 125).

W niniejszym studium przyjrzymy się jednemu z tych tekstów, który znajduje się na kartach Latopisu helleńskiego i rzymskiego drugiej redakcji ${ }^{1}$. Wspomniany utwór jest niewątpliwie unikatowym zabytkiem średniowiecznej historiografii ruskiej. Jego anonimowi autorzy starali się ukazać początki państwa Rurykowiczów na szerokim tle historii powszechnej. Swą narrację rozpoczęli zatem, zgodnie z rozpowszechnioną $\mathrm{w}$ literaturze wschodniochrześcijańskiej tradycją, od stworzenia świata, a następnie zaprezentowali obszerny skrót wydarzeń starotestamentowych, opis podbojów Aleksandra Wielkiego, a także historię Rzymu (od założenia Miasta do początku IV w. n.e.) oraz będącego jego sukcesorem Bizancjum. Wykład dziejów powszechnych doprowadzili do czasu rządów cesarza bizantyńskiego Romana I Lekapena (919-944), współczesnego księciu ruskiemu Igorowi (912-945) (Творогов 1999, s. I).

Autorzy Latopisu helleńskiego $i$ rzymskiego bazowali zarówno na zabytkach staroruskiej historiografii, jak i na tekstach proweniencji bizantyńskiej, przede wszystkim na przekazie kroniki Jana Malalasa oraz dzieła Jerzego Mnicha wraz z jego anonimową kontynuacją (Лихачев 1948, s. 104; Клосс 1972, s. 371-375; Творогов 1975, s. 141-143; Творогов 1999, s. I-II; Творогов 2001, s. 64; Бобров 2004, s. 86-87; Колесов 2004, s. 91; Водолазкин 2008, s. 230-231; Вилкул 2015, s. 372). Źródeł tych nie czytali jednak w oryginale greckim, poprzestając na ich

\footnotetext{
${ }^{1}$ Był on podstawą kilku późniejszych przekazów ruskich, poruszających problematykę narodzin islamu, np. opowieści, zawartej w Iluminowanym zwodzie latopisarskim, РНБ, F.IV.151, fol. 677-683' (Творогов 1974, s. 356).
} 
przekładach na język staro-cerkiewno-słowiański, wykonanych najprawdopodobniej w Bułgarii pod koniec X w., lub też w pierwszych dekadach XI w., a następnie przewiezionych na Ruś (Мещерский 1978, s. 78-79, 88-89; Творогов 1987, s. 468-470; Творогов 1999, s. IV; Матвеенко, Щеголева 2000, s. 532-543; Творогов 2001, s. 64-72; Анисимова 2009, s. 28). Analizowany utwór jest tekstologicznie zależny od słowiańskich tłumaczeń obu wspomnianych wyżej kronik ${ }^{2}$.

Poświęcona założycielowi islamu sekwencja, zatytułowana O heretyku Mahomecie (Ш Бохнитє єөєтиц $\mathbf{6}$ ), obejmuje - wraz z umiejscowionym bezpośrednio po niej opisem pierwszych najazdów wojsk arabsko-muzułmańskich na terytoria cesarstwa bizantyńskiego - około 12 kolumn tekstu półustawem w będącym podstawą edycji Olega V. Tvorogova rękopisie БАH, 33.8.13, datowanym na ostatnią tercję XV w. (fol. 224b-227a) (Творогов 1999, s. 402-405), w prezentowanym zaś tu manuskrypcie РГБ, собр. Пискарева (228), № 162 z 1485 r. - dwie i pół karty tekstu półustawem (fol. 342-344'). Narracja ta nie jest jednak oryginalnym utworem staroruskim, lecz relatywnie wiernym zapożyczeniem ze staro-cerkiewno-słowiańskiego przekładu kroniki Jerzego Mnicha (Истрин 1920, s. 449-454], wykonanego - jak wspominałam wyżej - w X/XI stuleciu. Warto tu odnotować, iż tłumaczenie to charakteryzuje się - zdaniem wielu badaczy - niezwykłą wiernością względem greckiego oryginału i prezentuje bliższą protografowi wersję tekstu niż niektóre zachowane odpisy bizantyńskie (Swoboda 1965, s. 468; Brzóstkowska 2011, s. 66).

Jerzy Mnich (Hamartolos), autor kroniki, będącej podstawą źródłową analizowanego tu fragmentu Latopisu helleńskiego i rzymskiego drugiej redakcji, tworzył w Konstantynopolu za panowania cesarza Michała III (842-867). Ponieważ od epoki, w której nauczał Mahomet, a wyznający islam Arabowie przypuścili swój pierwszy atak na Bizancjum, dzieliło go około 200 lat, w pracy nad interesującą nas tu częścią dzieła posiłkował się przekazami wcześniejszych twórców. I tak, stricte historiograficzne sekwencje, opisujące młodość i pierwsze objawienia Mahometa (par. 1-5) oraz najazd wojsk arabskich na wschodnie tereny cesarstwa bizantyńskiego (par. 15), zostały przez Jerzego Mnicha skompilowane na podstawie, spisanej w języku greckim, kroniki Teofanesa (około 760-818). Co ciekawe, ten ostatni autor, niebędący również naocznym świadkiem działalności Mahometa, opracowując sekwencje dotyczące Arabów, czerpał z tekstów syryjskich, m.in. z dzieła Teofila z Edessy (około 695-785), przetłumaczonego na grekę w Palestynie w 2. połowie VIII w. (Khoury 1969, s. 181-182; Hoyland 1997, s. 401-406, 452;

\footnotetext{
2 Omówienie poszczególnych redakcji źródła wraz z przeglądem zachowanych rękopisów znajdzie Czytelnik w artykule: Brzozowska 2017, s. 25-40.
} 
Mango i Scott 1997, s. XXXII-XXXIII, 464-470; Ziaka 2002/2003, s. 127; Thomas i Roggema 2009, s. 305-306, 426-431, 729-731; Максимов 2012, s. 65-66).

Najobszerniejszą część analizowanej opowieści (par. 6-14) stanowi natomiast swego rodzaju tekst polemiczny, prezentujący najważniejsze - zdaniem naszych autorów - dogmaty islamu i elementy obrzędowości/obyczajowości muzułmanów. I ta partia narracji Jerzego Mnicha jest treściowo zależna od źródeł wcześniejszych. Fragment, oznaczony w niniejszym studium jako paragrafy 6-8, zaczerpnięty został z niezrachowanego do naszych dni w formie całościowej traktatu Michała Synkellosa (około 760-846), wschodniochrześcijańskiego autora o arabskich korzeniach, tworzącego po grecku. $\mathrm{W}$ jednym z bizantyńskich odpisów kroniki Jerzego Mnicha, znajdującym się obecnie w zbiorach Biblioteki Narodowej Francji (MS BNF Coislin 305, fol. 312'), odnajdujemy wzmiankę, iż w tekst o Mahomecie został wpleciony wcześniejszy utwór autorstwa Michała Synkellosa (Georgius Monachus 1904, s. 699; Hunger 1978, s. 261; Thomas i Roggema 2009, s. 632, 731). Co ciekawe, fragment analizowanego dzieła - w znacznym stopniu zbieżny z sekwencją zachowaną w obrębie kroniki Hamartolosa - odnajdujemy również w trzeciej redakcji Nomokanonu 14. Rozdziatów, powstałej na zlecenie patriarchy konstantynopolitańskiego Tarazjusza (784-806) i przetłumaczonej na język staro-cerkiewno-słowiański najprawdopodobniej już w X wieku. Najstarszym istniejącym odpisem tego przekładu jest tzw. Kormcza Efrema, rękopis staroruski, datowany na początek XII w. (ГИМ, Син. 227) (Beneševič 1906, s. 701-704; Maksimovich 2007, s. 9-18).

Pozostała część omawianego tekstu (par. 9-14) jest najprawdopodobniej oryginalnym utworem pióra Jerzego Mnicha. Informacje na temat wyobrażeń religijnych muzułmanów czerpie on tu, co prawda, z wcześniejszych przekazów, m.in. poświęconego islamowi rozdziału traktatu $O$ herezjach Jana Damasceńskiego (około 675-754) ${ }^{3}$ oraz Rozmowy Saracena z chrześcijaninem, za którego autora uznawany jest bądź ten ostatni twórca, bądź też jego arabskojęzyczny uczeń, Teodor Abu Kurra $(740 / 750-820 / 830)^{4}$, niemniej jednak nadaje im swój własny koloryt (Khoury 1969, s. 181-182; Thomas i Roggema 2009, s. 439-440, 731; Максимов 2012, s. 66; Wolińska 2015, s. 544-545). Jak podkreślają badacze, od wcześniejszych autorów

\footnotetext{
3 Tekst ten znany był na Rusi najprawdopodobniej od lat 70. XIII w., tj. od okresu upowszechniania się na interesującym nas tu obszarze Nomokanonu św. Sawy, kompilacji prawnej, wykonanej w Serbii około 1219 roku. Najstarszym wschodniosłowiańskim odpisem tego zabytku jest tzw. Рязанская Кормчая z 1284 r. (РНБ, F.п.II.1 - Толст. отд. I, 311). W Kormczej Efrema (ГИМ, Син. 227) oraz jej późniejszych kopiach (tzw. staroruskiej redakcji Księgi Kormczej), a także w odpisach Ruskiej Kormczej (nр. Новгородская Синодальная кормчая z 1282 r. - ГИМ, Син. 132), zamiast rozdziału o islamie autorstwa Jana Damasceńskiego zamieszczono fragment traktatu Michała Synkellosa (Beneševič 1906, s. 701-704; Щапов 1978, s. 119, 261-270; Miklas 1981, s. 331-343; Petrović 1991, f. 369'-373'; Petrović 1997, s. 7; Maksimovich 2007, s. 11; Bushkovitch 2010, s. 125-126).

${ }^{4}$ Istnienie słowiańskiego przekładu Rozmowy Saracena z chrześcijaninem jest zagadnieniem oczekującym na opracowanie. Na obecnym etapie badań można jedynie stwierdzić, że tekst ten pojawia się w rękopisach ruskich, np. РГБ, ТСЛ , ф. 304.I (201), fol. 263-267 (XVII w.) (Bushkovitch 2010, s. 129-130).
} 
wschodniochrześcijańskich, piszących o Mahomecie i islamie (m.in. cytowanych tu Teofanesa i Michała Synkellosa), Jerzego Mnicha odróżnia wyjątkowo ostry i bezkompromisowy ton wypowiedzi. Zażarcie polemizuje on z muzułmanami, nie szczędząc im nieprzyjaznych, a często nawet - wręcz obraźliwych epitetów (Khoury 1969, s. 182; Максимов 2012, s. 66; Muhammad 2012, s. 298; Muhammad 2014, s. 81; Wolińska 2015, s. 558-559) .

Jerzy Mnich był też najprawdopodobniej pierwszym twórcą bizantyńskim, który podjął próbę wyjaśnienia sensu muzułmańskiego wyznania wiary (takbir), wypowiadanego w języku arabskim: ربكأ رل (Allāhu akbar - Bóg jest wielki). Hamartolos zapisał je ,ze słuchu”, transkrybując interesującą nas tu frazę na alfabet grecki. Ostatecznie uzyskała ona w jego dziele postać: 'A $\lambda \lambda \alpha$ 'A $\lambda \lambda \alpha$ Oơó Kovßá $\rho$ A $\lambda \lambda \alpha$. Zdaniem naszego autora, należy ją tłumaczyć: Bóg, Bóg jest większy niż Wielka, tj. księżyc i bogini Afrodyta (Georgius Monachus 1904, s. 706; Muhammad 2012, s. 298-300, 305; Muhammad 2014, s. 81-83, 89). Jerzy Mnich wypaczył zatem sens takbiru, interpretując go jako modlitwę skierowaną m.in. do Afrodyty, którą - według niego - Arabowie mieli czcić zarówno w okresie przedmuzułmańskim, jak i po wystąpieniu Mahometa. Należy w tym miejscu podkreślić, iż przeświadczenie, że lud ten oddawał cześć Afrodycie, którą utożsamiał z Gwiazdą Poranną (tj. planetą Wenus) i nazywał w swoim języku Wielką, jest toposem obecnym w literaturze antycznej od czasów Herodota. Stwierdzenia tego rodzaju odnaleźć możemy w pismach wielu autorów chrześcijańskich, m.in. Epifaniusza z Salaminy, św. Hieronima, Teodoreta z Cyru, Prokopiusza z Cezarei, Ewagriusza Scholastyka, patriarchy konstantynopolitańskiego Germana i Jana Damasceńskiego. Sądy te znajdują do pewnego stopnia potwierdzenie w materiale archeologicznym - Arabowie w okresie przedmuzułmańskim rzeczywiście czcili bóstwa żeńskie, m.in. Al-Uzzę, którą zhellenizowani mieszkańcy Nabatei i Palmyry utożsamiali z Afrodytą (Brzozowska 2015).

Reasumując, narrację Jerzego Mnicha na temat narodzin islamu, a tym samym także - opowieść zawartą w Latopisie helleńskim i rzymskim drugiej redakcji, należy uznać za tekst niezwykle mocno osadzony we wschodniochrześcijańskiej tradycji literackiej. Zawiera on zapożyczenia z utworów wielu wcześniejszych autorów, z których niektórzy żyli w tej samej epoce co Mahomet i mieli mniej lub bardziej bezpośrednią styczność z Arabami.

\footnotetext{
${ }^{5}$ Co ciekawe, Jerzy Mnich (a w ślad za nim anonimowi autorzy Latopisu helleńskiego i rzymskiego drugiej redakcji), przypisując Mahometowi wszelkie najgorsze cechy charakteru, koncentruje się jedynie na tzw. „mekkańskim” okresie (610-622) jego biografii, w którym wiódł on spokojny żywot kupca, zaś prywatnie - był wiernym mężem Chadidży. Całkowitym milczeniem pomija natomiast „okres medyński” (622-632), który mógłby dostarczyć mu obszernego materiału faktograficznego, pomagającego skompromitować założyciela islamu w oczach chrześcijańskich czytelników. Paradoks ten jest zagadnieniem wymagającym gruntowniejszego opracowania.
} 
Treść kroniki Jerzego Mnicha w staro-cerkiewno-słowiańskim przekładzie została w interesujących nas tu fragmentach Latopisu helleńskiego i rzymskiego drugiej redakcji przytoczona w całości, bez skrótów i bez jakichkolwiek odautorskich uzupełnień. Różnice ograniczają się tylko do poziomu stylistycznego i redakcyjnego, wyjąwszy zmiany, wynikające najprawdopodobniej z niezrozumienia przez kopistę sensu oryginału. $\mathrm{W}$ prezentowanym tu polskim tłumaczeniu zabytku, w tych partiach narracji, w których tekst odpisu РГБ, собр. Пискарева (228), № 162 sprawiał wrażenie uszkodzonego i niezrozumiałego, wprowadzono korekturę treści zgodnie z rękopisem РГБ, собр. Ундольского (310), № 1289 - będącym podstawą przygotowanej przez V. Istrina edycji słowiańskiej wersji kroniki Hamartolosa. Ingerencje tego rodzaju oznaczono kursywą. W analogiczny sposób zasygnalizowano też miejsca, w których obecne w tekście staroruskim wulgaryzmy (np. БлAдম́ство) zastąpiono określeniami bardziej neutralnymi znaczeniowo.

Kilka istotniejszych zmian, wprowadzonych przez autorów staroruskich do przekazu Jerzego Mnicha, wyszczególniono poniżej:

- W Latopisie helleńskim i rzymskim, podobnie jak w przekładzie kroniki na język scs, Mahomet określany jest mianem truciciela (отравьникъъ) - w tekście greckim odnajdujemy natomiast sformułowanie metaforyczne, które należy raczej rozumieć jako odniesienie do herezji, zatruwającej ludzkie dusze i umysły.

- Dość problematyczny był dla autorów staroruskich fragment poświęcony takbirowi. Afrodyta, której rzekomo mieli oddawać cześć Arabowie, w jednym zdaniu staje się idolem/bogiem Afrodytem, zaledwie zaś kilka wersów niżej - odzyskuje swój właściwy rodzaj gramatyczny. Dalszemu zniekształceniu ulega też brzmienie muzułmańskiego wyznania wiary, transliterowanego tu (z omyłkami) z alfabetu greckiego na cyrylicki.

$* * *$

Tekst staroruski Latopisu helleńskiego i rzymskiego drugiej redakcji został wydany przez Olega V. Tvorogova (Творогов 1999), na podstawie rękopisu БАН, 33.8.13, z uwzględnieniem lekcji z kilku innych odpisów. Całościowych przekładów zabytku na języki nowożytne brak. Tłumaczenie kroniki Jerzego Mnicha na język staro-cerkiewno-słowiański opublikowano już na początku XX w. (Истрин 1920). Istnieje również edycja oryginalnego tekstu greckiego dzieła Hamartolosa (Georgius Monachus 1904). Bizantyński oryginał utworu oraz jego wersja słowiańska nie były tłumaczone na języki nowożytne w pełnej postaci. Współczesny przekład rosyjski (Матвеенко і Щеголева 2000) został wykonany na podstawie rękopisu, reprezentującego starszą redakcję tłumaczenia staro-cerkiewno-słowiańskiego, w którym opis wydarzeń urywa się na roku 553. Opowieść o Mahomecie i narodzinach islamu, zaczerpnięta z kroniki Jerzego Mnicha, została przełożona 
na język rosyjski przez Jurija Maksimova, na podstawie edycji tekstu greckiego z 1904 r. (Максимов 2012, s. 68-73).

\section{TEKST ŹRÓDŁA W ORYGINALE STARORUSKIM}

Tekst wg odpisu РГБ, собр. Пискарева (228), № 162, datowanego na 1485 rok. Rękopis ten jest dostępny w wersji elektronicznej w bazie: http://old.stsl.ru/ manuscripts/index.php. Segmentacja tekstu pochodzi od autorki niniejszej edycji i nawiązuje do podziału, zaproponowanego przez Jurija Maksimova (Максимов 2012, s. 68-73). Marginalia zamieszczono w przypisach, z odnotowaniem miejsca w tekście głównym, obok którego się znajdują.

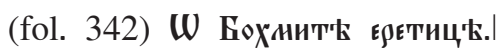

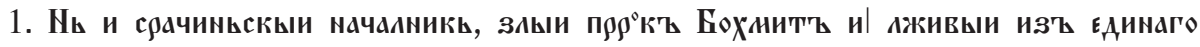

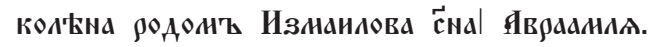

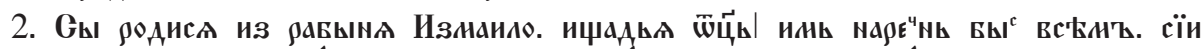

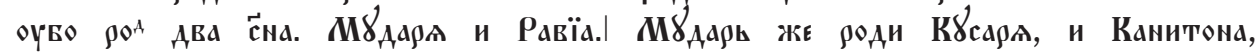

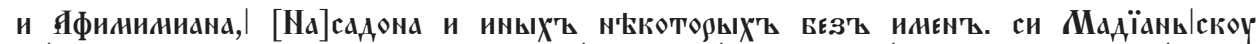
п४стыню nacА'九доваша. и 'котты питах

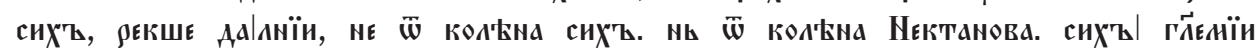
Шинритани. ${ }^{6+}$

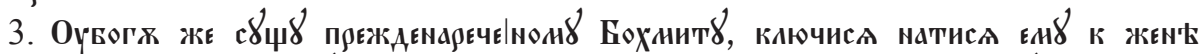

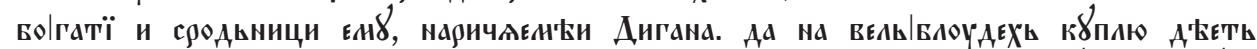

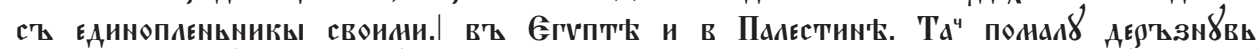

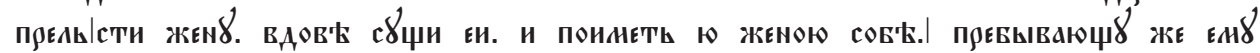

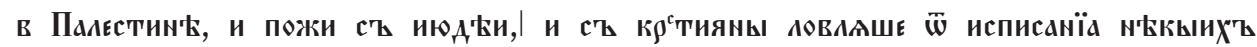

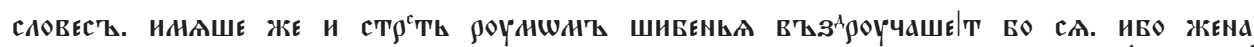

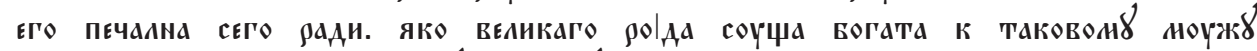

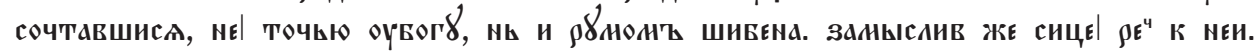

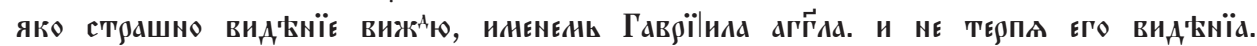
ИЗНЕНОГАЮ ИЗ

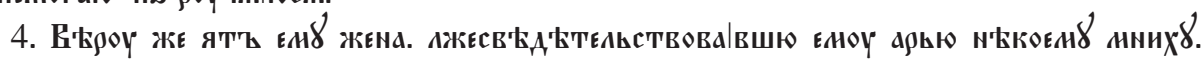

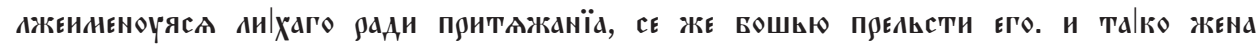

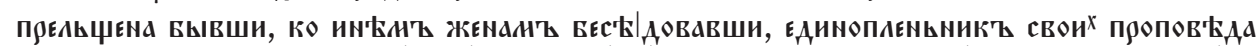
ин,

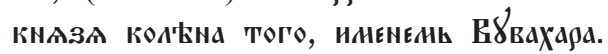

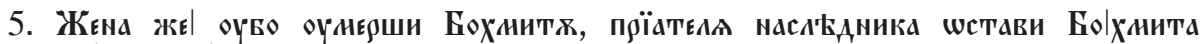

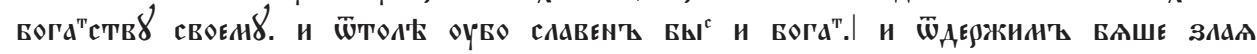

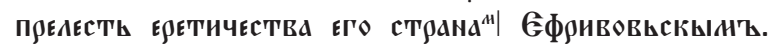

\footnotetext{
6 рекше Янанине.
} 


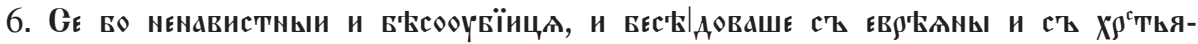

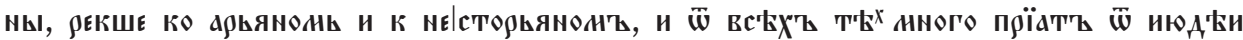

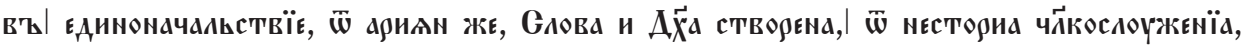

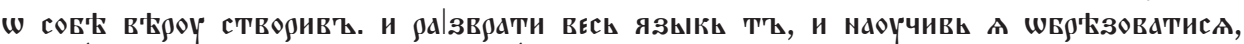

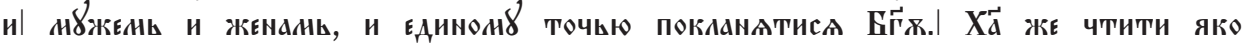

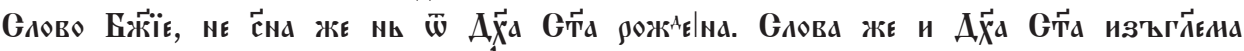

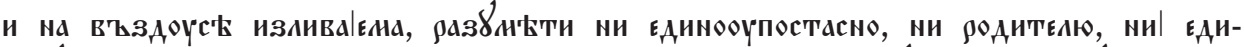

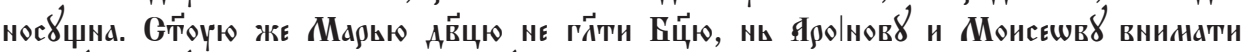

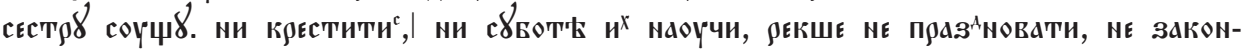

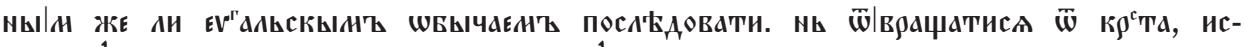
тиньн

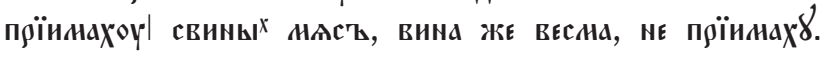

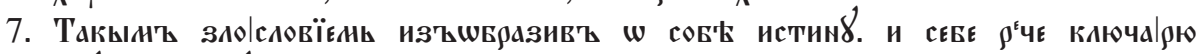

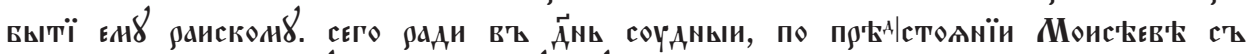

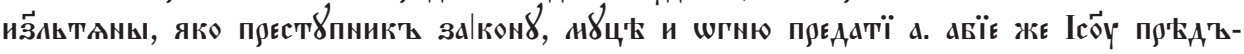

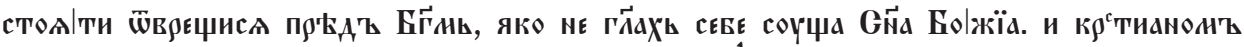

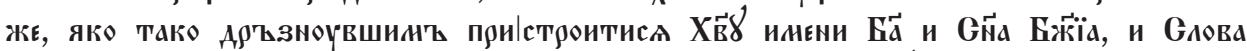

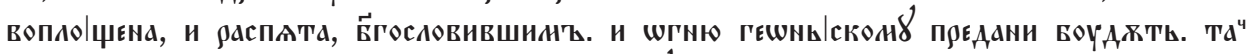

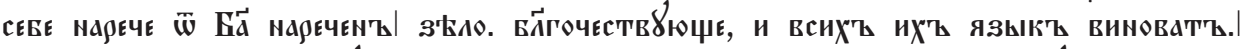

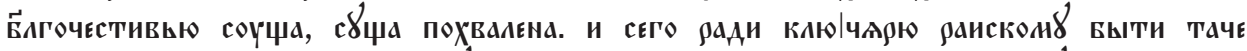

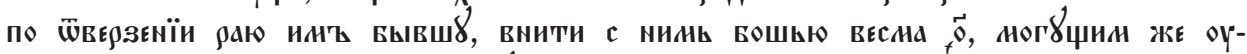

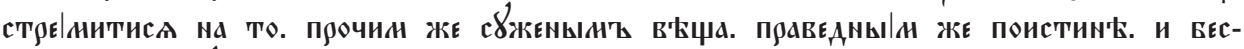

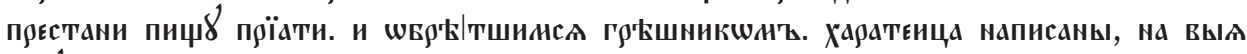

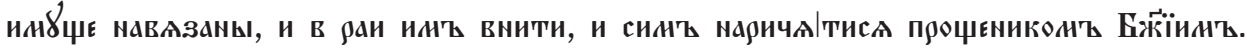

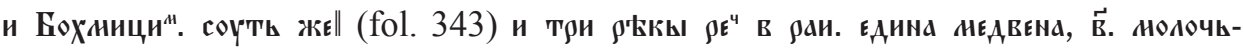

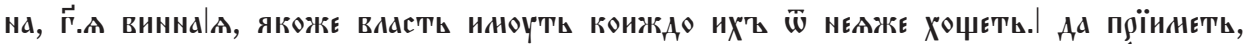

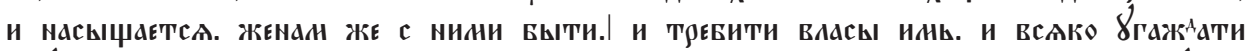

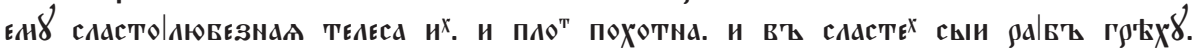

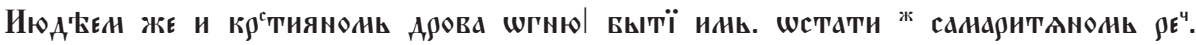

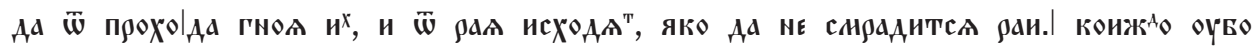

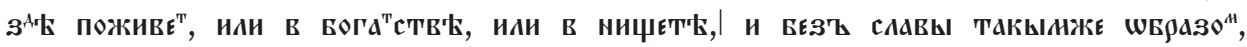

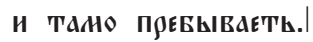

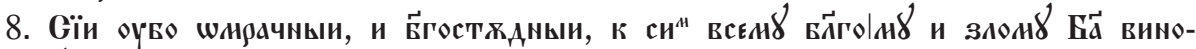

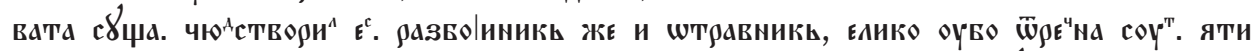

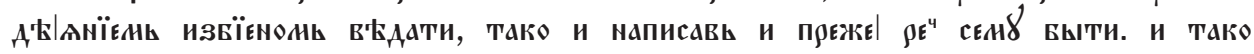

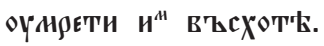

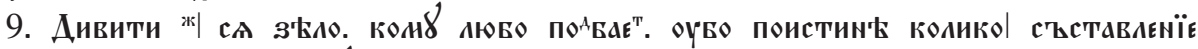

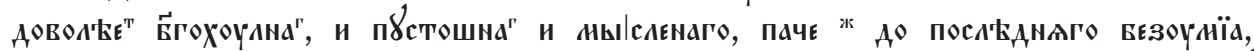

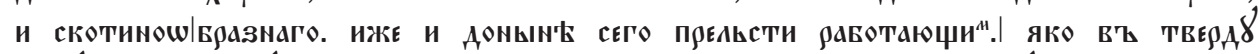

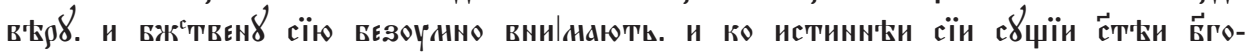

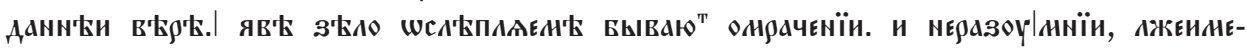

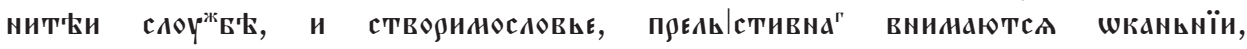




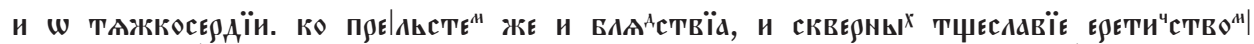

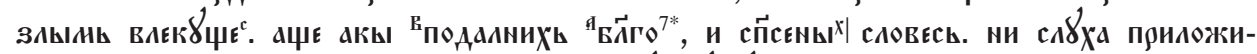

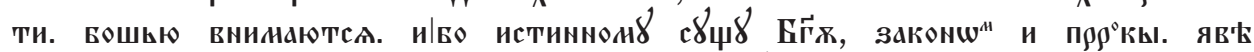

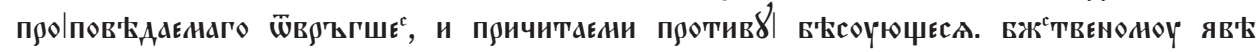

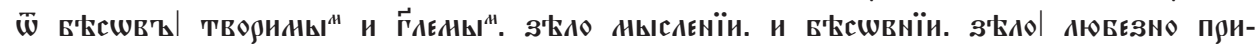
стоүпаю".

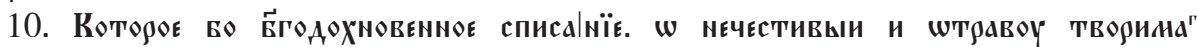

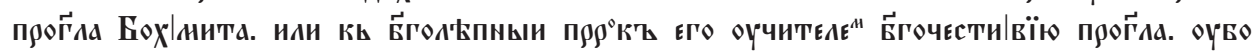

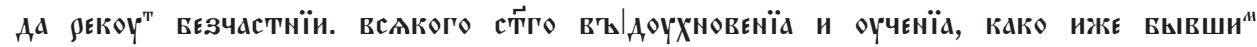

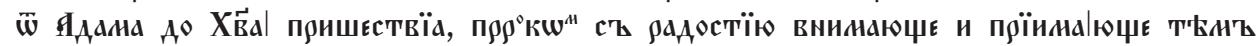

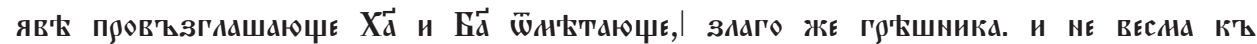

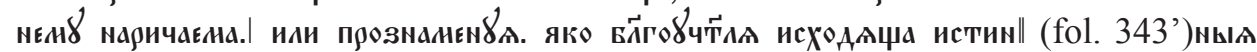

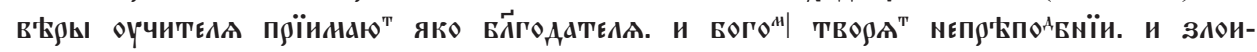
МЕнกї̈.

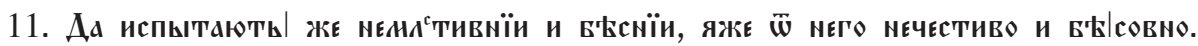

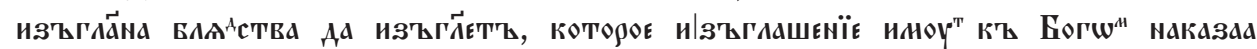

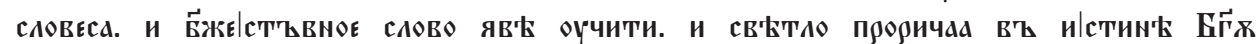

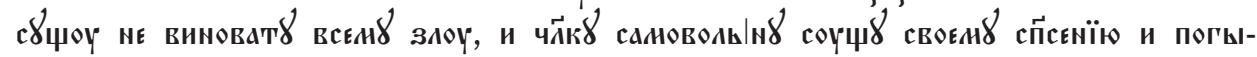

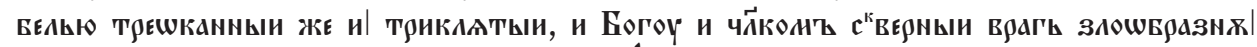

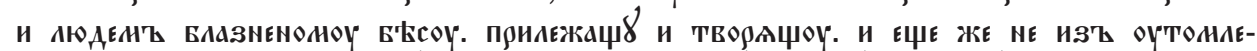

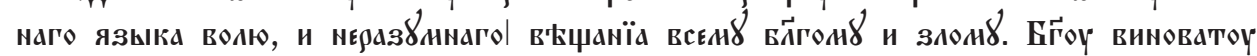

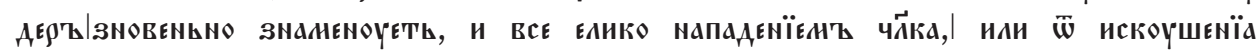

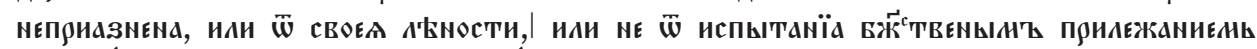

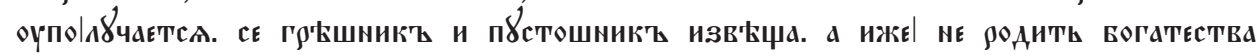

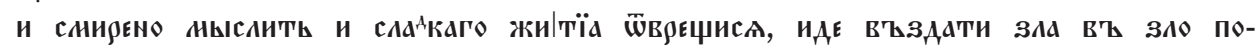

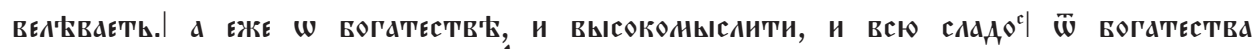

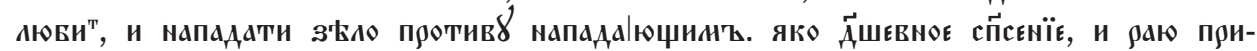
частї̈.

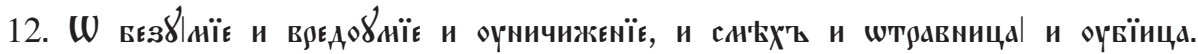

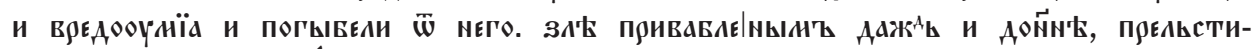

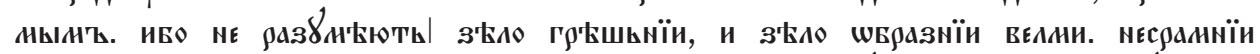

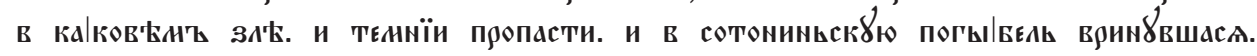

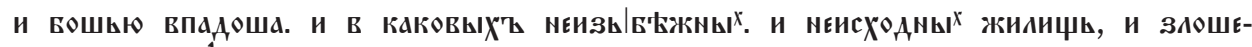

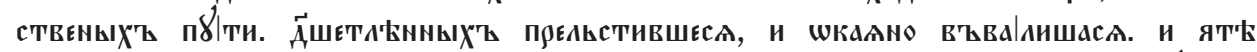

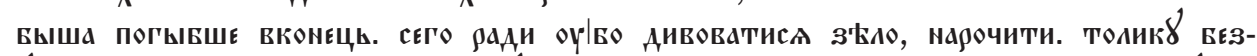

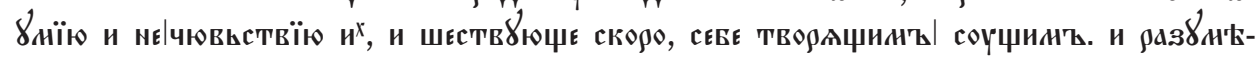

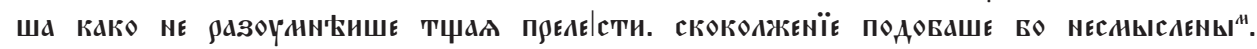

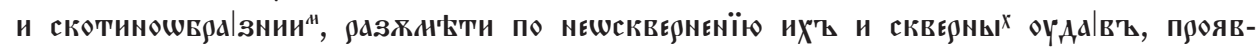

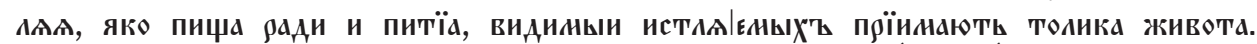

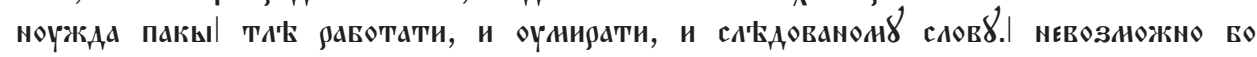

7 Б̈г поданых. 


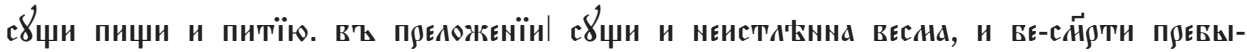

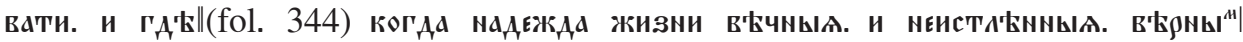

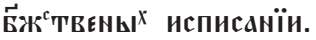

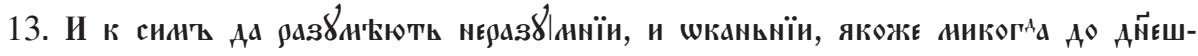

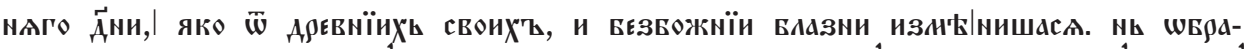

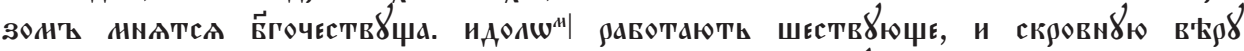

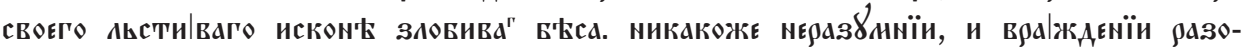

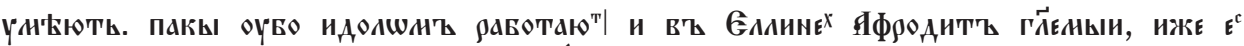
СКАЗаЕно сладе

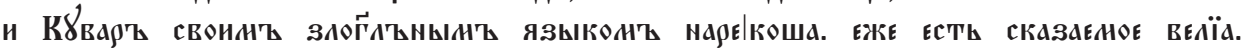

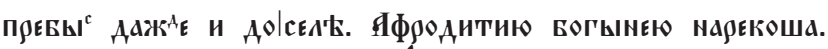

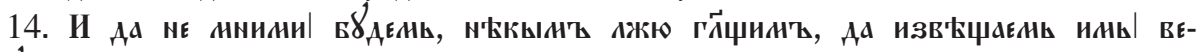
лик

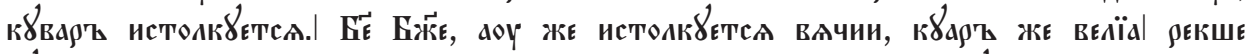
А

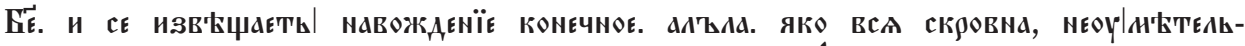

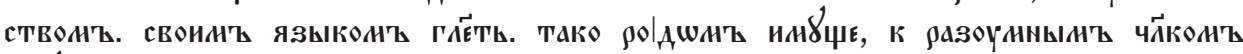

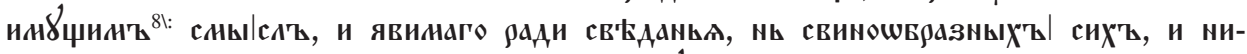

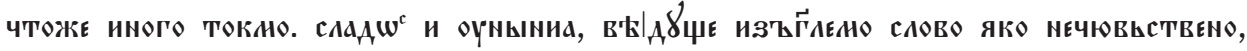

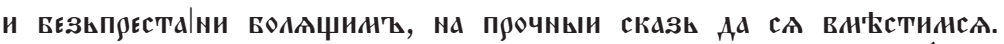

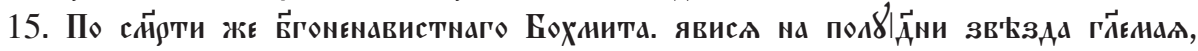

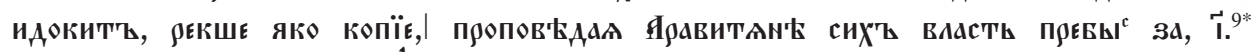

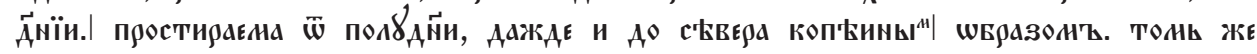

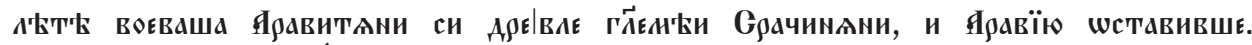

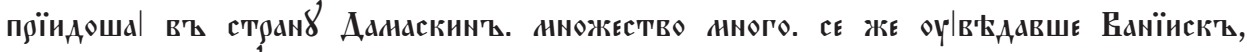

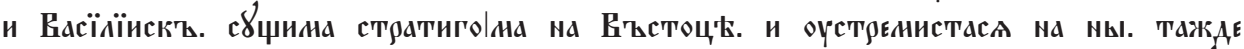

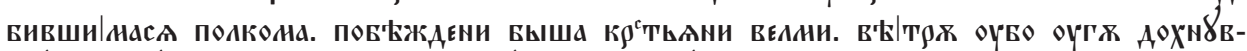

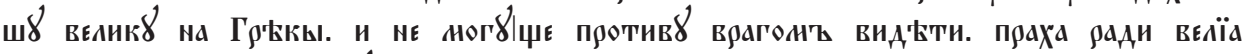
и ЗА'

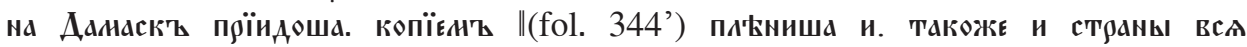

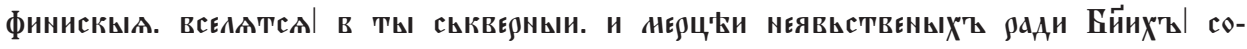
YAEE'L.

\section{PRZEKŁAD POLSKI}

Wszelkie uzupełnienia i wyjaśnienia, pochodzące od tłumaczki, zamieszczono w nawiasach kwadratowych. Informacje zawarte w marginaliach podano natomiast w nawiasach klamrowych. Rekonstruowane partie tekstu oraz miejsca, w których

\footnotetext{
8 ин'ъ.

$9 * \dot{\Lambda}$.
} 
obecne w oryginale staroruskim wulgaryzmy zastąpiono sformułowaniami bardziej neutralnymi znaczeniowo, zapisano kursywą.

\section{O heretyku Mahomecie}

1. Saraceński przywódca Bohmit [Mahomet], prorok zły i fałszywy, wywodził się z jednego z plemion Izmaela, syna Abrahama.

2. Tenże Izmael narodził się z niewolnicy i został nazwany ojcem ich wszystkich - [swojego] potomstwa. Spłodził on dwóch synów: Mudara i Rabię. Mudar zaś zrodził Kusara, Kanitona, Afimimiana, Sadona i jeszcze kilku innych, nieznanych z imienia. Oni to odziedziczyli pustynię Midian i żywili się bydłem, żyjąc w namiotach. Są też wśród nich [szczepy] wewnętrzne, to znaczy bardziej oddalone, nie z ich plemienia, lecz z rodu Nektara, zwane Homerytami \{czyli Amanitami\}.

3. Ponieważ wspomniany wyżej Mahomet był ubogi, przyszło mu nająć się [do pracy] u bogatej kobiety, spokrewnionej z nim, zwanej Digana [Chadidża], aby na wielbłądach prowadzić handel wraz ze swoimi pobratymcami w Egipcie i w Palestynie. Później, stopniowo nabrawszy śmiałości, zwiódł tę owdowiałą kobietę i pojął ją za żonę. Kiedy przebywał w Palestynie i stykał się z żydami i z chrześcijanami, wyławiał z ich pism niektóre słowa. Cierpiał on też na porażenie umysłu - padał [w atakach epilepsji]. Jego żona była $\mathrm{z}$ tego powodu rozżalona. [Ubolewała], że choć wywodziła się ze znacznego rodu i była bogata, związała się z takim oto mężczyzną: nie tylko ubogim, ale jeszcze porażonym na umyśle. Zrozumiawszy to, rzekł jej więc tak: „Straszną wizję widzę, anioła o imieniu Gabriel i nie mogąc znieść tej wizji, tracę siły i padam".

4. Kobieta dała temu wiarę, kiedy fałszywie zaświadczył [jej] o nim pewien arianin, dla korzyści podający się kłamliwie za mnicha. On to jeszcze bardziej go zwiódł. I tak kobieta, zostawszy okłamaną, rozmawiając z innymi kobietami ze swojego plemienia, obwieściła im, że on [Mahomet] jest prorokiem. Zwiodła je i tak kłamstwo doszło do mężczyzny, księcia tegoż plemienia, o imieniu Bubahara.

5. [Później] zmarła żona Mahometa, ustanowiwszy go właścicielem i dziedzicem swojego majątku. I odtąd był on sławny i bogaty, a złe kłamstwo jego herezji owładnęło krainami Efribu [Jatribu].

6. Był on zaś przepełnionym nienawiścią szatańskim zabójcą. Wiódł dysputy z żydami i z chrześcijanami, tj. z arianami i z nestorianami, i od nich wszystkich wiele przejął: od żydów - monoteizm, od arian - [ideę] stworzonego Słowa i Ducha, od nestorian zaś - antropolatrię. I stworzywszy własną wiarę, podburzył cały ten lud. I nauczył ich obrzezywać mężczyzn i kobiety, oddawać cześć jednemu tylko Bogu, Chrystusa czcić jako Słowo Boże, a nie jako Syna, zrodzonego za sprawą Ducha Świętego. Słowo i Ducha Św. [nakazał on] uważać za coś wypowiedzianego i rozlewającego się w powietrzu, a nie [byty] współhipostatyczne, 
współistotne Rodzącemu [je]. Świętej Dziewicy Marii nie należy zwać Bogurodzicą, lecz [wypada] uznawać ją za siostrę Aarona i Mojżesza. Nauczył ich też [Mahomet] nie chrzcić się, nie świętować sobót, nie przestrzegać obyczajów, ustanowionych w Prawie i w Ewangelii, lecz odwracać się od krzyża i wierzyć, że ukrzyżowany Chrystus był cieniem. Nauczeni [tak], całkowicie odrzuciwszy prawo, nie przyjmowali świńskich mięs i wina w ogóle nie pili.

7. Za pomocą takich to oszczerstw stworzył [Mahomet] prawdę o sobie. Mówił, że on sam jest klucznikiem raju. Z tego powodu w dzień Sądu, po wystąpieniu Mojżesza z Izraelitami, zostaną oni wydani na mękę i [na pastwę] ognia jako przestępcy wobec Prawa. Potem zaś wystąpi Jezus, zaprzeczając przed Bogiem: „nie mówiłem o sobie, że jestem Synem Bożym”. I chrześcijanie - gdyż ośmielili się dodać do imienia Chrystusa Boga i Syna Bożego oraz nauczać o Wcielonym Słowie i Ukrzyżowanym - zostaną wydani ogniowi Gehenny. [Mahomet] o sobie zaś rzekł, że [zostanie] uznany przez Boga za niezwykle pobożnego, a że za jego sprawą cały ich lud stał się pobożnym - stanie się godnym wysławiania. I z tego powodu będzie on klucznikiem raju. A kiedy raj zostanie przez niego otworzony, wejdzie z nim do niego tylko 70000 [ludzi], mogących poważyć się na to. Pozostali zaś - jak głosi - zostaną osądzeni. Sprawiedliwi będą prawdziwie i bez ustanku zażywać słodyczy, grzesznicy zaś, którzy się tam znajdą, [powinni] mieć przywiązane na szyjach zapisane pergaminy, aby wejść do raju i zwać się wyzwoleńcami Boga i Mahometa. Są zaś, rzekł on, trzy rzeki w raju: jedna - miodu, druga - mleka, a trzecia - wina. I każdy z nich będzie mieć prawo, z której zapragnie, zaczerpnąć i nasycić się. Kobiety przebywać będą razem z nimi, kunsztownie zdobić swoje włosy i dogadzać mu na wszelkie sposoby. Ich ciała [będą] rozkochane w rozkoszy i pełne pożądania, on zaś wśród rozpusty [będzie] niewolnikiem grzechu.

Żydzi i chrześcijanie będą drzewami w ogniu i pozostaną, a samarytanie - rzekł [Mahomet] - ze względu na wydalany przez nich gnój, niech z raju uchodzą, aby nie zasmradzali raju. Każdy bowiem, kto żyje tutaj [tj. na tym świecie] albo w bogactwie, albo w ubóstwie i niesławie, w takiej samej kondycji będzie przebywać tam [tj. w raju].

8. Ten oto tonący $\mathrm{w}$ mroku przeciwnik Boga mówił także potworności, że za każde dobro i zło odpowiedzialny jest Bóg. Złoczyńców, trucicieli i wszystkich schwytanych na jakiejkolwiek zakazanej czynności, należy publicznie zabijać. Tak napisał, a wcześniej rzekł: „Tak ma być”. I zapragnął, by w ten sposób umierali.

9. Można się dziwić wiele - każdy, ile chce - że naprawdę twór do tego stopnia bluźnierczy, miałki i wydumany, a nawet [będący] szczytem głupoty i zezwierzęcenia, jeszcze i obecnie zjednuje sobie niewolników, którzy uważają go nierozumnie za mocną i Boską wiarę! I bywają całkowicie zaślepieni, [by móc dojrzeć] prawdziwą wiarę, świętą i daną od Boga. Zamroczeni i bezrozumni przestrzegają samozwańczego obrzędu i wymysłów kłamcy. Nieszczęśnicy - pociąga ich okrucieństwo, kłamstwo, rozwiązłość, nieczysta pycha i zła herezja, a ku bło- 
gosławionym, \{pochodzącym od Boga\} i zbawczym słowom wcale nie skłaniają ucha. Wyrzekli się bowiem prawdziwego Boga, o którym jawnie naucza Prawo i Prorocy, a przyłączywszy się do pieklącego się otwarcie przeciwko Boskości, przystępują bardzo chętnie do biesowskich uczynków i niezwykle wydumanej, diabelskiej mowy.

10. Które to bowiem natchnione przez Boga pismo przepowiedziało tego bezbożnego i trującego [dusze ludzkie] Mahometa? Albo który podobający się Bogu prorok nazwał go nauczycielem pobożności? Niech więc powiedzą, pozbawieni wszelkiego świętego natchnienia i nauczania: jak mogą, ochoczo uznając i przyjmując proroków, będących od Adama do przyjścia [na świat] Chrystusa, odrzucać wprost przez nich ogłaszanego Chrystusa i Boga? Podłego zaś grzesznika, którego tamci wcale nie nazywają i nie przepowiadają, [mogą] uznawać za ostatniego z proroków, nauczyciela prawdziwej wiary i dobroczyńcę, [a nawet] czynić go Bogiem - bezbożni i bez prawego imienia?

11. Niechaj zostaną zapytani, ci niemiłosierni i wściekli, o obrzydlistwa, wypowiedziane przez niego bezbożnie i szatańsko, i niech powiedzą, jaki związek mają one ze słowami pochodzącymi od Boga. Słowo Boże jasno naucza i wyraźnie stwierdza, że Bóg naprawdę nie jest winny wszelkiemu złu, a człowiek ma wolną wolę $\mathrm{w}$ kwestii swojego zbawienia lub potępienia. Ten zaś po trzykroć nieszczęsny i przeklęty, zawzięty wróg Boga i człowieka, działając pod wpływem szpetnego i zwodzącego ludzi biesa, zuchwale rozgłasza - nieposkromionym wolą językiem i bezrozumną mową, że Bóg jest całkowicie odpowiedzialny za dobro i zło. Ten bajdurzący grzesznik obwieścił, że cokolwiek przydarza się człowiekowi, czy to wskutek szatańskiej pokusy, czy to jego własnego lenistwa, czy to nieszczęścia, dzieje się z Bożej inicjatywy. Nie nakazuje [Mahomet] także unikania bogactwa, skromnych myśli, wyrzekania się rozkosznego trybu życia $i$ nie odpłacania złem za zło. [Uznaje] zaś bogactwo, pychę, zamiłowanie do wszelkiej rozkoszy wypływającej $z$ bogactwa oraz zawzięte atakowanie atakujących za zbawienne dla duszy i drogę do raju.

12. O, jakaż jest głupota i obłęd, [budzące] wzgardę i śmiech, tego truciciela i zabójcy, a także zgubny obłęd tych, którzy zostali przez niego zwabieni ku złu i aż do dzisiaj są okłamywani! Nie pojmują bowiem wcale - niezwykle grzeszni, zezwierzęceni i całkowicie bezwstydni - w jakie zło, ciemną otchłań i szatańską zgubę zostali wrzuceni i całkowicie się pogrążyli; w do jakiego stopnia pozbawionych możliwości ucieczki i wyjścia siedzibach oraz na jak trudnych do przejścia i zgubnych dla duszy ścieżkach utknęli, zwiedzeni i nieszczęśliwie pochwyceni, ostatecznie zginęli! Z tego też względu należy dziwić się niezwykle tak wielkiej ich głupocie i niewrażliwości: idąc szybko, uważają się za rozumnych, a nie pojmują słabości [swego] czczego łgarstwa. Powinni bowiem - głupi i zbydlęceni zrozumieć, iż jest nieczystą siecią ich [nauka] o zmartwychwstaniu, zakładająca, że otrzymują w tamtym życiu widzialne i podlegające rozkładowi [tj. materialne] jadło i napoje. Wynika $z$ tych słów bowiem konieczność bycia niewolnikiem 
rozkładu i śmierci. Nie jest bowiem możliwe, przyjmując pokarmy i napoje, istnieć jako byt przeistoczony, całkowicie niepodlegający rozkładowi i nieśmiertelny. I gdzie jest, w takim wypadku, nadzieja na życie wieczne i niematerialne, właściwa tym, którzy wierzą w Boże pisma?

13. Powinni również pojąć, nierozumni i nieszczęśni, że jeszcze nigdy aż do dnia dzisiejszego nie odstąpili od swoich dawnych i bezbożnych błędów, lecz strojąc się w pozór pobożności, potajemnie służą idolom, nie rozumiejąc w żaden sposób skrytej wiary swego kłamliwego i od zarania srogiego biesa, głupi i porażeni. Nadal zatem służą idolom, [bóstwu] nazywanemu przez Hellenów Afrodyt, co znaczy 'rozkosz', i oddają pokłon gwieździe, bajając, że jest to Jutrzenka [Gwiazda Poranna], którą w swoim oszczerczym języku nazwali Habar, co znaczy 'wielka'. Trwali [przy tym] nawet do czasów obecnych i nazywali Afrodytę boginią.

14. Aby zaś się nie wydawało, że przekazujemy jakieś kłamstwa, wyjawiamy tu ich wielką tajemnicę - parszywa ich modlitwa ma takie oto nieczyste słowa: 'adla ua kuwar'. Tłumaczy się: 'Boże, Boże'; 'au' tłumaczymy jako 'najpotężniejszy'; 'kuar' zaś jako 'wielka', tj. księżyc i Afrodyt. [Całość] brzmi więc tak: 'Boże, boże najpotężniejszy, wielka, to znaczy księżycu i Afrodycie boże'. I na to wskazuje dodane na końcu 'alla'. Ponieważ skrywają to wszystko za nieznajomością swojego języka, mówią to tylko swoim pobratymcom [?]. Otwarcie nie chca jednak objawić tych rzeczy ludziom mądrym, posiadającym rozum, z powodu [lęku] przed jawnym poznaniem. Lecz opowiedziawszy o tych, podobnych do świń i nieznających niczego innego niż rozkosz i zniechęcenie, nieodczuwalnie i nieuleczalnie chorych, powróćmy do głównej opowieści.

15. Po śmierci nienawidzącego Boga Mahometa pojawiła się na południu gwiazda, zwana 'idokit', co znaczy 'w kształcie kopii', zwiastując [nastanie] władzy tych oto Arabów. Była przez 10 [30] dni, rozpostarta od południa aż do północy na podobieństwo kopii. Tegoż roku rozpoczęli wojnę Arabowie, wcześniej zwani Saracenami, opuściwszy Arabię, przybyli w okolice Damaszku w wielkiej liczbie. Kiedy dowiedzieli się o tym Baanes i Bazylisk, będący strategami na Wschodzie, wyruszyli przeciwko nim. Później, gdy starły się [ich] wojska, chrześcijanie zostali srodze rozgromieni: ponieważ uderzył na Greków silny wiatr z południa, nie mogli oni spoglądać w stronę wrogów, z powodu olbrzymiego pyłu. I tak zostali okrutnie zwyciężeni. Saraceni, zwyciężywszy, z mocą i ze znacznymi siłami przybyli pod Damaszek i wzięli go szturmem. Takoż i wszystkie tereny Fenicji. Osiedlili się $\mathrm{w}$ nich, nieczyści i obrzydliwi, za sprawą nieprzeniknionych Bożych wyroków. 


\section{BIBLIOGRAFIA}

Beneševič V.N. 1906, Syntagma XIV titulorum sine scholiis secundum versionem Palaeo-Slovenicam, adjecto textu Graeco e vetustissimis codicibus manuscriptis exarato, t. 1, Petropoli, Typis Academiae Scientiarum Imperialis Petropolitanae.

Brzozowska Z.A. 2015, The Goddesses of Pre-Islamic Arabia (Al-Lāt, Al- 'Uzzā, Manāt), w: T. Wolińska, P. Filipczak (red.), Byzantium and the Arabs: the Encounter of Civilizations from Sixth to Mid-Eighth Century, Łódź, Wydawnictwo Uniwersytetu Łódzkiego, s. 55-82.

Brzozowska Z.A. 2017, Butgarski car Piotr i jego żona Maria Lekapena w Latopisie helleńskim i rzymskim drugiej redakcji, ,Slavia Antiqua” 58, s. 25-40.

Brzóstkowska A. 2011, Kroniki z kręgu Symeona Logotety, w: A. Brzóstkowska (red.), Testimonia najdawniejszych dziejów Stowian. Seria grecka, t. 5. Pisarze z X wieku, Warszawa, Slawistyczny Ośrodek Wydawniczy. Instytut Slawistyki PAN, s. 64-67.

Bushkovitch P. 2010, Orthodoxy and Islam in Russia 988-1725, w: L. Steindorff (red.), Religion und Integration im Moskauer Russland. Konzepte und Praktiken, Potentiale und Grenzen 14.-17. Jahrhundert, Wiesbaden, Harrassowitz Verlag, s. 117-143.

Georgius Monachus 1904, Chronicon, C. de Boor (red.), t. 2, Leipzig, In Aedibus B.G. Teubneri.

Hoyland R.G. 1997, Seeing Islam as Others Saw It. A Survey and Evaluation of Christian, Jewish and Zoroastrian Writings on Early Islam, Princeton, The Darwin Press.

Hunger H. 1978, Die hochsprachliche profane Literatur der Byzantiner, t. 1. Philosophie, Rhetorik, Epistolographie, Geschichtsschreibung, Geographie, München, C.H. Beck'sche Verlagsbuchhandlung.

Khoury A.-Th. 1969, Les Theologiens byzantins et l'Islam. Textes et auteurs (VIIIe-XIIIe s.), LouvainParis, Editions Nauwelaerts.

Maksimovich K. 2007, Byzantine Law in Old Slavonic Translations and the Nomocanon of Methodius, Byzantinoslavica, 65, s. 9-18.

Mango C., Scott R. (red.) 1997, The Chronicle of Theophanes Confessor. Byzantine and Near Eastern History. AD 284-813, Oxford, Clarendon Press.

Miklas H. 1981, Zur kirchenslavischen Überlieferung der Häresiengeschichte des Johannes von Damaskus, „Monumenta Linguae Slavicae” 15, s. 323-387.

Muhammad T.M. 2012, Allā Wa Koubar in the Byzantine Conception, „Pax Islamica” 1-2, s. 296-315.

Muhammad T.M. 2014, The Concept of Al-takbīr in the Byzantine Theological Writings, "Byzantinoslavica" 72, s. 77-97.

Petrović M.M., red. 1991, Zakonopravilo or the Nomocanon of Saint Sava. The Ilovica Manuscript from 1262. Photoprint reproduction, Gornji Milanovac, Dečje Novine.

Petrović M.M. 1997, Saint Sava's Zakonopravilo on the Teachings of Muhammed, Belgrade, Novi dani.

Swoboda W. 1965, Kontynuacja Georgiosa, w: W. Kowalenko, G. Labuda, T. Lehr-Spławiński (red.), Słownik starożytności słowiańskich. Encyklopedyczny zarys kultury Słowian od czasów najdawniejszych do schyłku wieku XII, t. 2, Wrocław-Warszawa-Kraków, Zakład Narodowy im. Ossolińskich, Wydawnictwo Polskiej Akademii Nauk, s. 468.

Thomas D., Roggema B. (red.) 2009, Christian-Muslim Relations. A Bibliographical History, t. 1. 600-900, Leiden-Boston, Brill.

Wolińska T. 2015, Elity chrześcijańskie wobec islamu (VII-X w.), "Vox Patrum" 64, s. 529-567.

Ziaka A.G. 2002/2003, Le regard que port la recherche grecque contemporaine sur la découverte de l'islam par le monde byzantin (VIII ${ }^{e}-X I V^{E}$ s.), Le Courrier du GERI. Recherches d'islamologie et de théologie musulmane 5/6, s. 119-142.

Анисимова Т.В. 2009, Хроника Георгия Амартола в древнерусских списках XIV-XVII вв., Москва, Издательство Индрик.

Анисимова Т.В. 2010, Рогожский хронограф: текст, w: О.Л. Новикова, red., Летописи и хроники. Новые исследования. 2009-2010, Москва-Санкт-Петербург, Научное издательство Альянс-Архео, s. 102-161.

Батунский М.А. 2003, Россия и ислам, t. 1, Москва, Издательство Прогресс-Традиция. 
Бобров А.Г. 2004, К вопросу о времени и месте создания Летописиа Еллинского и Римского второй редакции, „Труды Отдела древнерусской литературы” 55, s. 82-90.

Вилкул Т. 2015, Літопис і хронограф. Студї з домонгольського київського літописання, Київ, Інститут історії України.

Водолазкин Е.Г. 2008, Всемирная история в литературе Древней Руси (на материале хронографического и палейного повествования XI-XV вв.), Санкт-Петербург, Издательство Пушкинский Дом.

Истрин В.М. 1920, Книги временные и образные Георгия Мниха. Хроника Георгия Амартола в древнем славянорусском переводе. Текст, исследование и словарь, t. 1, Петроград, Российская государственная академическая типография.

Клосс Б.М. 1972, К вопросу о происхождении Еллинского летописиа второго вида, „Труды Отдела древнерусской литературы" 27, s. 370-379.

Клосс Б.М. 1980, Никоновский свод и русские летописи XVI-XVII вв., Москва, Издательство Наука. Колесов В.В. 2004, Заметки о языке Летописиа Еллинского и Римского второй редакиии (К вопросу о месте и времени составления), „Труды Отдела древнерусской литературы” 55, s. 91-97.

Летописный сборник, 2000, именуемый Патриаршею или Никоновскою летописью, Москва, Полное собрание русских летописей 9.

Летопись по Воскресенскому списку, 1856, Санкт-Петербург, Полное собрание русских летописей 7.

Лихачев Д.С. 1948, Еллинский летописеи второго вида и правительственные круги Москвы кониа $X V$ в., „Труды Отдела древнерусской литературы” 6, s. 100-110.

Лихачев Д.С. 1979, Поэтика древнерусской литературы, Москва, Издательство Наука.

Лицевой летописный свод XVI в., 2014, Всемирная история, t. 8, Москва, Издательство Актеон.

Максимов Ю.В. 2012, Византийские сочинения об исламе, Москва, Православный Свято-Тихоновский гуманитарный университет.

Матвеенко В., Щеголева Л. 2000, Временник Георгия Монаха (Хроника Георгия Амартола). Русский текст, комментарий, указатели, Москва, Издательство Богородский печатник.

Мещерский Н.А. 1978, Источники и состав древней славяно-русской переводной письменности $I X-X V$ вв., Ленинград, Издательство ЛГУ.

Русский хронограф, 1911, Хронограф редакиии 1512 г., Санкт-Петербург, Полное собрание русских летописей 22.1 .

Русский хронограф, 1914, Хронограф Западнорусской редакиии, Петроград, Полное собрание русских летописей 22.2 .

Творогов О.В. 1974, О составе и источниках хронографических статей Лицевого свода, „Труды Отдела древнерусской литературы” 28, s. 353-364.

Творогов О.В. 1975, Древнерусские хронографы, Ленинград, Издательство Наука.

Творогов О.В. 1987, Хроника Георгия Амартола, w: Д.С. Лихачев (red.), Словарь книжников и книжности Древней Руси (XI - первая половина XIV в.), Ленинград, Издательство Наука, s. $469-470$.

Творогов О.В. 1989, Материаль к истории русских хронографов 3. Троицкий хронограф, „Труды Отдела древнерусской литературы" 42, s. 287-343.

Творогов О.В. 1999, Летописеи Еллинский и Римский, t. 1. Текст, Санкт-Петербург, Издательство „Дмитрий Буланин”.

Творогов О.В. 2001, Летописеи Еллинский и Римский: текстологические проблемы, „Труды Отдела древнерусской литературы" 52, s. 47-78.

Щапов Я.Н. 1978, Византийское и южнославянское правовое наследие на Руси в XI-XIII в., Москва, Издательство Наука. 